\title{
An overview of Irish pig production, research and knowledge transfer since 1960
}

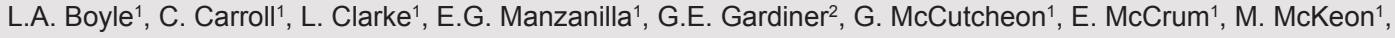 \\ P.G. Lawlor ${ }^{1}$, B. Lynch ${ }^{1}$, J. O'Doherty ${ }^{3}$ and K. O’Driscoll ${ }^{1+}$ \\ ${ }^{1}$ Pig Development Department, Teagasc, Animal \& Grassland Research \& Innovation Centre, Moorepark, Fermoy, Co. Cork, P61 C996, \\ Ireland \\ ${ }^{2}$ Department of Science, Waterford Institute of Technology, Co. Waterford, X91 K0EK, Ireland \\ ${ }^{3}$ School of Agriculture and Food Science, University College Dublin, Belfield, Co. Dublin, D04 F6X4, Ireland
}

Abstract

Pig production in Ireland has gone through enormous changes during the past $60 \mathrm{yr}$, from pigs being primarily produced as a sideline on dairy farms, to an industry with one of the highest average herd sizes in Europe. This happened in part due to external pressure on the industry, whereby economies of scale were needed to compete with pigs produced in other countries, but largely due to the instigation of national programmes to support the pig industry through research, education and knowledge transfer. These efforts helped producers to take advantage of genetic improvements and monitor their own performance over time, as well as allowing for benchmarking of the national herd against other countries. The research programme initiated in the 1960 s continues to grow and expand, providing the pig industry with internationally renowned data and knowledge in the areas of nutrition, animal welfare, the environment and energy use. Recent initiatives such as the establishment of the Teagasc and Irish Farmers Association Pig Joint Programme, and a Pig Health Check section in Animal Health Ireland, will help to promote further cross-collaboration between stakeholders in the pig industry, and enable it to rise to the challenges of the years ahead.

Keywords

Environment $\bullet$ health $\cdot$ legislation $\cdot$ management $\bullet$ nutrition $\cdot$ performance

\section{Introduction}

Pig production is a major sector of the agricultural economy of Ireland. It ranks third in gross agricultural output (8\%) after milk and beef, and the value of pig meat exports in 2020 was almost $€ 1$ billion. Traditionally, pigs were produced alongside the dairy sector, as historical by-products of dairy production (whey and skim milk) provided an excellent and cheap source of feed for pigs. However, the structure of the pig sector in Ireland transformed during the past $60 \mathrm{yr}$. In 1960, there were 111,000 pig famers with an average herd size of eight pigs, and a national output of $\leq 1$ million pigs. Today Ireland has 280 commercial pig farms comprising $\sim 200$ sow breeding/ integrated farms with an average herd size of $\sim 700$ sows and $\sim 80$ specialised finishing farms, and a national output of 3.8 million pigs (Teagasc, 2021 personal communication).

Up to the 1960s, most farms comprised of small breeders with a few sows producing pigs for finishing on their own farms, or for sale to specialised finisher farms. An initiative undertaken in the 1960s by the Department of Agriculture (Department of Agriculture, Food and the Marine [DAFM] today) was the development of pig cooperatives where small breeders could sell their weaned pigs at 25-30 kg live weight for finishing in a central farm. This allowed small breeders a share in the profit from finishing pigs to slaughter. However, it soon emerged that mixing of pigs from several farms resulted in disease incidence, which led to this system ceasing. Thus, over time, the production model in Ireland evolved from small breeding and specialised finisher farms, to the "integrated pig farm" which breeds, rears and finishes pigs all produced on the same farm.

\section{The Teagasc Pig Development Department}

One of the most significant developments for the Irish pig sector occurred in 1959, when Dr Jim O'Grady was appointed to the Moorepark Research Centre (part of the new agricultural research institute to become known as An Foras Talúntais, 
AFT). Because of the close linkages between pigs and milk production at farm level at the time, it was decided that pig research should be located at the same campus as the dairy research centre. Jim was tasked with developing the facilities and programme that would provide the vital technology for what was to become an internationally competitive pig production sector. His initial team included technicians Tom Gardiner and Sean Scanlon, who oversaw the construction of an 80-sow farm with farrowing pens and dry sow accommodation on straw, with individual feeders. Indeed, in 1968 Moorepark was one of the first farms in Ireland to fit individual stalls for pregnant sows to allow tailored feeding for individual animals. A strategic programme was developed aimed at providing the technologies for housing, feeding and fertility that would revolutionise the Irish pig industry over the following decades.

Early experiments focused on feeding sows during pregnancy and lactation. Subsequently, the first major experiment compared the Jordan (an uninsulated concrete structure originally used in Northern Ireland, later to become known as the "sweat box"), the Solari (a hayshed-type structure with kennels, under which the pigs slept with straw stored on top) and the Danish house (the most expensive of the three, it had a single feeding passage through the centre and small pens on each side, with a feed trough parallel to the passage).

In the late 1960s, the research team was further strengthened with the recruitment of two new scientists, Tom Hanrahan and Brendan Lynch. This led to a massive expansion in the research programme, especially in the area of feeding and nutrition, and subsequent dramatic improvements in the efficiency of pig production at farm level. The late 1960s saw the development of the "Moorepark Diet", a barley-soya bean meal diet, which became the standard diet for finisher pigs and, with subsequent improvements over the years, it remains the benchmark diet to date in Ireland. Moorepark also developed blueprints on housing and hygiene, which enabled the further development of large farms.

\section{Knowledge transfer}

Dissemination of research from Moorepark and further afield came about via nationally funded advisory services, operated over the years by the Department of Agriculture, the County Committees of Agriculture, the national advisory and training body (ACOT) and currently, by Teagasc. In 1970, two young agricultural graduates, Pat Tuite and Michael Martin, were appointed Specialist Pig Advisors by the Department of Agriculture. As the pig sector developed, it became clear that specialisation was needed and Pat and Michael put together a national team of eight Specialist Pig Advisors in the early 1980s. In the mid-1990s, the pig research and advisory departments were amalgamated into the Pig Development Department (PDD).

\section{Education}

Skilled staff, motivated to deliver a high level of technical performance, are essential in pig production. Education and training for staff to supply the pig sector was initially provided at Mellows College, Athenry where the Certificate in Pig Husbandry trained managers and skilled stock persons for the industry from 1969 to 2003. Numbers in the first year of the course peaked at 32. However, a greater range of training options outside agriculture and the fall from favour of narrow agriculture-only courses in general contributed to the demise of the course. The final intake of six was in 2000 and of these, four graduated in 2003. This created a dearth of skilled labour, which in the short term was part-filled by foreign-born labour, particularly from Eastern Europe. However, in 2009 the PDD initiated a level-5 certificate in Agriculture (Pig Production; National Framework of Qualifications Level 5) which has since trained 140 students. A level 6, advanced certificate in agriculture (Pig Management), followed in 2018.

\section{The joint programme}

The PDD has always worked closely with pig farmers, and in 2012 Teagasc and the Irish Farmers Association agreed on a "Pig Joint Programme", which facilitated the recruitment of additional researchers, advisors and technical support for the research and advisory programme. This led to a significant increase in the capability of the PDD. On the research side, the PDD currently hosts $\sim 12$ postgraduate students and 4 postdoctoral researchers at any one time, compared to $\sim 4$ and 2 , respectively, prior to the joint programme's establishment. Along with this, in 2016 a newly built Teagasc Pig Research Facility, which could accommodate 200 sows and their offspring, opened in Moorepark. This facility contains stateof-the-art feeding systems (both wet and dry), a "baby-feed" system for pre-weaned and immediately weaned pigs, as well as specialised facilities and equipment to measure individual pig intake, detailed animal behaviour testing and measures of physical condition (e.g. blood sampling, hoof scoring, etc.). With regard to knowledge transfer activities, this greater critical mass allowed the PDD to establish multiple outreach activities which were previously not possible, through a dedicated communication officer. These activities include a monthly newsletter, a bi-monthly podcast "The Pig Edge", a dedicated Twitter account, an annual research dissemination day, facilitated pig farmer discussion groups across all regions of the country, a regularly updated suite of infographics and posters for use on pig farms, and a YouTube "skills series". In addition, the Pig Research Facility releases a video diary every month, so that stakeholders can stay up to date with research and performance indicators. The success of the joint programme is evidenced in the results of an external peer review across all the livestock sectors in Teagasc, carried out in 2017. Not only did the PDD rank highest within Teagasc, 
but the Peer Assessment Panel described the PDD as "one of the largest and arguably best applied pig research/extension programmes operating globally today".

\section{Improvements in performance}

Key performance indicators (KPIs) are important in the management of any business, as they enable business owners to make decisions using data, and monitor those decisions. Teagasc Pig Advisors have worked with pig producers over the years to develop a number of industry-relevant KPIs. These were initially collated from the mid-1990s using the Teagasc PigSys recording system, and in 2014 the system was switched to the Teagasc eProfit Monitor (ePM) recording system. Participating pig farmers submit their data to their Teagasc Advisor on a quarterly basis, and the data from all participating farms are compiled and published by Teagasc as the "National Pig Herd Performance Report" each year. Although not available since 1960 (when the average litter size was 11.4 piglets, sows produced 15 pigs/yr and feed conversion efficiency from weaning to sale was 4.0 ), annual data are compiled since 2000.

Data were collected from 141 farms in 2000 (average of 400 sows/herd), 98 farms in 2010 (average of 654 sows/herd) and 88 farms in 2020 (average of 799 sows/herd). The database currently represents over $55 \%$ of the Irish sow herd.

\section{KPls over the years}

Table 1 provides an overview of the main KPIs used in the Irish pig industry and provides values for 2000, 2010 and 2020. Numbers born alive (BA) per litter have risen steadily with a $30 \%$ increase between 2000 and 2020. Although the number of litters per sow per year is stable, this meant an increase of $28 \%$ in pigs produced (sold) per sow per year in 2020 relative to 2000. Between 2000 and 2020, there was an increase in live sale weight of $25.2 \mathrm{~kg}$, and an increase in deadweight (carcass weight) of $20.1 \mathrm{~kg}$. Indeed, average daily gain (ADG) from weaning to sale has improved by $150 \mathrm{~g}$ per day over the same period. The increase in pigs produced/sow per year and carcass weight of each pig has contributed to more pig meat sold/sow per year (an increase of 66\% between 2000 and 2020). The amount of feed required to produce each kilogram of carcass is also decreasing over time, and can be seen in the drop from 3.66 to $3.50 \mathrm{~kg}$ of feed to produce a kilogram of pig meat.

\section{The market for pig meat}

In 1960, Ireland recorded an annual pig throughput of just under 1 million pigs (3.8 $\mathrm{m}$ today) equating to $71,586 \mathrm{t}$ of pig meat valued at almost IR£160 $\mathrm{m}$. Slaughter pigs were
Table 1: Key performance indicator values from the Irish pig industry in 2000, 2010 and 2020

\begin{tabular}{lccc}
\hline & $\mathbf{2 0 0 0}$ & $\mathbf{2 0 1 0}$ & $\mathbf{2 0 2 0}$ \\
\hline Measures of sow performance & & & \\
$\quad$ Litters/sow per year & 2.29 & 2.32 & 2.31 \\
Born alive/litter & 10.85 & 12.01 & 14.26 \\
Piglet mortality \% & 9.0 & 9.9 & 11.1 \\
Weaner mortality \% & 2.6 & 2.4 & 2.8 \\
Finisher mortality \% & 2.3 & 2.5 & 2.7 \\
Pigs produced/sow per year & 21.5 & 23.9 & 27.5 \\
Performance weaning to sale & & & \\
Liveweight at sale (kg) & 90.1 & 103.6 & 115.3 \\
Deadweight at sale (kg) & 68.1 & 78.9 & 88.2 \\
ADG (g) & 585 & 668 & 735 \\
Feed conversion efficiency & 2.34 & 2.47 & 2.40 \\
Pigmeat produced & & & \\
Carcass weight sold/sow per year (kg) & 1471 & 1886 & 2426 \\
Total feed/sow (kg) & 5385 & 6966 & 8488 \\
kg feed/kg of carcass & 3.66 & 3.69 & 3.50 \\
\hline
\end{tabular}

(Source: Teagasc PigSys herd recording system, 2000, 2010, replaced by Teagasc eProfit Monitor, 2020).

*This is the pigs produced/sow/year multiplied by the average deadweight at sale.

ADG = average daily gain .

processed in 38 factories or "curers" operating at the time at various locations throughout the country. The organisation of the pig meat market throughout the 1960s remained under the control of the Pigs and Bacon Act (PBA) first introduced in 1935. The PBA and subsequent amendments were a set of national measures aimed at stabilising the market, which was subject to large fluctuations, to ensure orderly and reasonably profitable pig production on the island. Established in 1939 under the PBA, the Pigs and Bacon Commission regulated the production and marketing of pig meat and was responsible for managing Irish pig meat exports via a quota arrangement with individual curers.

The shift to modern pig management systems from the mid1980s brought about major rationalisation and investment in the sector, which helped Ireland to develop an internationally competitive export-orientated pig meat industry (see Table 2). The impact of EU membership, government policy, technological developments and market forces influenced the type of pig products exported in the intervening years. Ireland is over $200 \%$ self-sufficient in pig meat and in recent years has shown exceptional growth in exports. In 2020, the Irish product was exported to over 50 different countries throughout 
Table 2: Details of the pig meat sector at 10 -year intervals from 1970 to 2020

\begin{tabular}{lcccc}
\hline & \multicolumn{2}{c}{ Gross output } & \multicolumn{2}{c}{ Exports } \\
\hline & Output $^{1}$ & Volume $^{2}$ & Volume $^{2}$ & Value $^{3}$ \\
\hline 1970 & 1.93 & 128.7 & 45 & 68 \\
1980 & 2.38 & 154.3 & 54 & 87 \\
1990 & 2.37 & 156.9 & 54 & $\mathrm{n} / \mathrm{a}$ \\
2000 & 3.15 & 230.4 & 121 & 270 \\
2010 & 2.66 & 214.3 & 134 & 317 \\
2020 & 3.54 & 320.0 & 317 & 586 \\
\hline
\end{tabular}

Source: the Central Statistics Office

${ }^{1}$ Million head

${ }^{2}$ Thousand tonnes

${ }^{3}$ Million $€$

the world. The UK has remained a principal market for Irish pig meat exports dominating supplies since the 1960s. The outbreak of African swine fever (ASF) in 2018, particularly in China, dramatically reshaped the global meat market and its trade patterns. Shipments of Irish pig meat to the Asian market now account for $47 \%$ of the total volume and $41 \%$ of the total value of exports, with China being the leading destination for Irish product in 2020. Asian markets have now overtaken the UK market in terms of both volume and value for Irish pig meat exports. The UK market as our closest neighbours, however, will still remain a key market in the future for Irish pig meat accounting for $30 \%$ of the total value and $23 \%$ of the total volume of exports in 2020 (Bord Bia, 2021).

\section{Genetics and breeding}

One of the major reasons for the improvements in the aforementioned KPIs is a change in pig genetics. In the early 1960s in Ireland, the pig industry was composed of many small individual pig breeders, each specialising in one or two pig breeds. These breeders competed in national shows (e.g. the Irish Spring Show), for the prize of National Champion Boar for each individual breed. Indeed this national competition lasted until the mid-1980s. However, by that stage there was a significantly reduced number of Irish pig breeders, and along with an increased awareness of disease transmission/biosecurity and consequently a reluctance to risk bringing pigs to public shows/events, the competitions were no longer sustainable.

The development of larger pig farms from the 1960s, and the shift into modern pig production, coincided with the introduction of the Landrace and Large White breeds and their establishment as the predominant breeds. A government breeding programme in the mid-1960s, supported by the importation of high-quality breeding stock, brought about initial rapid improvements in carcass leanness. In more recent years, the pig breeding industry developed independently from government programmes, and since the 1990s a new model emerged. The number of Irish pig breeders declined until only Hermitage Pigs remained as the last of the original pedigree pig breeders in the Irish Pig Herd Book, and currently only four genetic sources supply the Irish market. This followed an international pattern, whereby since the 1990s the global pig genetic companies amalgamated. The large-scale uptake of artificial insemination (Al) in the commercial pig production sector means that today pig breeding is almost $100 \%$ by $\mathrm{Al}$. The dominant breeds remain the Landrace and Large Whites, with the Duroc breed also gaining in popularity in recent years.

\section{Rate of genetic change}

Adoption of $\mathrm{Al}$ in Ireland during the late 1980s means that at each service a high genetic merit boar can now inseminate 20 sows instead of one. National, and eventually international, Al delivery increased access to high genetic merit boars, contributing to the emergence of global pig genetic companies. These larger companies, along with the greater use of BLUP (Best Linear Unbiased Prediction) computing and genomic selection, allowed for increased accuracy and acceleration in genetic improvement for key performance/economic traits during the last $20 \mathrm{yr}$. Indeed, pigs were initially considered "dual purpose" (i.e. equally suited for breeding and finishing) but since the 1980s are separated into separate breeding goals for sire and dam lines.

The focus on dam-line fertility largely concentrated on 1) reduction of the weaning-to-service interval (WSI) and 2) increasing the number of piglets BA. Advances in fertility were initially made by individual breeders with small "nucleus" herds, and therefore genetic progression was slow, but this increased rapidly after the consolidation of the industry. This is evidenced by the increases in BA in Ireland (Table 1). Unfortunately, the strive for higher BA over this period was negatively correlated with birth weight, and positively correlated with within-litter variation in birth weight and increased pre-weaning mortality. Wientjes et al. (2012) estimated that the average birth weight fell by $40 \mathrm{~g}$ for every extra piglet born; therefore, over the last $20 \mathrm{yr}$ an increased BA of 4 pigs/litter equates to an estimated average reduction in birth weight of $160 \mathrm{~g} /$ piglet. As such, in recent years the industry introduced a "survivability by day $3 / 5$ " into their damline selection traits.

The split into separate breeding goals for sire-line and damline allowed for a significant increase in sire-line growth rates and feed efficiency (FE), and by extension, reduced back-fat and increased lean meat percentage. Indeed, these traits improved even though sale weight has increased steadily over the last $21 \mathrm{yr}$ (Table 1); the average growth rate from weaning 
to sale increased by $150 \mathrm{~g} /$ day ( $585 \mathrm{~g}$ to $735 \mathrm{~g}$ ) even though birth weight decreased by $\sim 160 \mathrm{~g} / \mathrm{pig}$ over the same period.

\section{The challenge of rearing large litters}

As a result of recent increases in litter size, sows are often not capable of rearing all of their own piglets to weaning, because the number of piglets increasingly exceeds the number of teats. Additionally, larger litters are associated with a decrease and variation in piglet birth weight, meaning piglets are increasingly susceptible to injury and death (Calderón Díaz et al., 2017). Thus, the genetic changes listed earlier have resulted in concurrent changes to sow and piglet management.

Cross-fostering (CF) is the practice whereby piglets are moved between sows to match piglet and teat numbers, and to even up piglet sizes within litters, when sows are all within the same farrowing batch. It often occurs throughout lactation, although usually during the first week. Results from a recent survey conducted on 79 Irish pig farms show that in $51.9 \%$ of farms CF takes place $4 \mathrm{~d}$ after farrowing and in $46 \%$ of farms, only late $\mathrm{CF}$ is practiced (unpublished data). However, movement is stressful for piglets (they need to repeatedly attempt to establish their own teat on the udder), and ultimately results in lighter carcass weights, greater risk of mortality and greater risk of pericarditis and heart condemnations (Calderón Díaz et al., 2017, 2018). Average daily gain was reduced by $21 \mathrm{~g} / \mathrm{d}$ for CF piglets, resulting in them being $\sim 550 \mathrm{~g}$ lighter than nonfostered piglets at weaning. Moreover, the heavier the piglet was at birth, the more detrimental the effect of CF (i.e. greater the differences in weaning weight between piglets that were or were not CF; O'Driscoll et al., manuscript in preparation). A piglet may end up being moved several times if care is not taken to monitor piglet movement, and as such Teagasc recommend tagging all CF piglets.

Nurse sow strategies are an alternative, highly structured, version of $\mathrm{CF}$, used when multiple sows in a batch have more piglets born than teats available. The nurse sow is a sow later into lactation. If her piglets are at least $21 \mathrm{~d}$ old, they are weaned, and if not, they are moved to another sow, who has had her own piglets moved off of her (again, weaned or moved to another sow). Newly born piglets from multiple large litters are then moved to the nurse sow at between 12 and $24 \mathrm{~h}$ after birth, once they consume colostrum from the mother. Thus a new litter of very young piglets is formed, rather than piglets entering an already established one.

Teagasc research found that when nurse sows were left without piglets for $3 \mathrm{~h}$, all accepted their new litter (Schmitt et al., 2019a). There was intense fighting between piglets at nursing during the first few days, which was associated with piglets completely missing nursing bouts, until the teat order was formed about 1 wk later (Schmitt et al., 2019b). Interestingly, this research also found that when piglets were moved as a litter to a new sow, there was an increase in piglets switching teats during nursing. This suggests that the teat order was disturbed just by the transfer onto a new sow, and highlights again that movement of piglets should be minimised (Schmitt et al., 2019b). In this research, the heavier piglets were moved from their mothers to form the nurse sow litters, which had the consequence of all litters being a similar weight at weaning; this has benefits for pig management later on in the production cycle. In addition, there was no evidence of compromised welfare associated with nurse sow strategies (Schmitt et al., 2019a).

Other options for management of large litters is provision of supplementary milk in the pen, or indeed a complete artificial rearing strategy. Pilot work in the Moorepark unit, which is being expanded upon in the coming years due to installation of a milk-feeding system in the farrowing and weaner rooms, indicates that a supplementary energy supply has benefits for weaning weight (O'Driscoll \& Schmitt, 2016). However, removing 7-day-old piglets from their mother, and artificially rearing them in a plastic enclosure with a milk-feeding system (Rescue Deck®) until $28 \mathrm{~d}$ of age, was not beneficial for growth. These piglets also had more harmful behaviours and were dirtier than sow-reared piglets (Schmitt et al., 2019c). Thus, artificial rearing is not a suitable strategy to rear piglets.

\section{Pig nutrition}

As feed costs account for $\sim 70 \%$ of pig production costs, improving $\mathrm{FE}$ is possibly the principal determinant of profitability in pig production. Since its inception, Teagasc conducted nutritional research on all phases of pig production, aiming to determine the most efficient feeding strategies, while optimising animal health and welfare.

\section{The sow}

Inadequate nutrition of the gestating sow can negatively influence both the sow and her offspring, immediately, and in the longer term, and thus have a significant effect on farm profitability. Teagasc has performed both gilt and sow nutrition research, as they may respond differently to dietary adjustments. For instance, in the early 2010s, Teagasc research determined that back-fat for gilts should be targeted at $\sim 19 \mathrm{~mm}$ by the time of first insemination. A daily feed allowance of $\sim 2.5 \mathrm{~kg}$ of gestation diet $(6.2 \mathrm{~g} / \mathrm{kg}$ total lysine, 13.0 MJ digestible energy [DE] $/ \mathrm{kg}$ ) should be provided to gilts between day 25 and 90 of gestation, to maximise growth to slaughter in offspring (Amdi et al., 2013, 2014).

A high proportion of Irish sows are liquid-fed. Frequently, producers inadvertently restrict the intake of liquid-fed sows during lactation by using feed curves (computerised plan of daily allocation of feed which increases during lactation) that do not provide sufficient feed to match the intake capacity of 
sows. This results in excessive lactation weight loss, increased days to oestrus, reduced farrowing rate and reduced litter size at the subsequent farrowing. Indeed, increasing commonly used feed curves by $30 \%$ reduced the number of days between weaning and oestrus, reduced excessive sow weight loss and potentially increased litter size by two piglets. Thus, increasing lactation feeding levels holds promise to increase subsequent litter size and reduce the number of empty days (days not pregnant or suckling their litter) per sow (Lawlor et al., 2007a; Ryan et al., 2009).

Large litters mean that there is increased pressure on the sow to produce healthy, efficient piglets. L-carnitine is a watersoluble quaternary amine, and plays a role in the transport of fatty acids across the mitochondrial membrane. Thus, it is hypothesised to improve energy generation through fatty acid oxidation. Supplementation to hyper-prolific gestating gilts ( 15 piglets born) not only increased the number of pigs weaned and litter weight at weaning, but also increased the carcass weight of offspring at slaughter (Rooney et al., 2019, 2020b). Moreover, supplemented sows gave birth to heavier piglets, particularly for sows with $>14$ piglets born. Carnitine also improved piglet vitality at birth (Reid et al., 2016). Thus, carnitine holds promise as an option to increase piglet survivability and growth where litters are large.

Energy intake depends both on the quantity of the diet consumed and on its energy density. Sufficient lactation energy intake is critical to maximise milk yield, minimise mobilisation of body reserves and maximise subsequent reproductive performance. Increasing the energy density of the lactating sow diet in increments from 13.8 to $15.9 \mathrm{MJ} \mathrm{DE} / \mathrm{kg}$ did not depress sow-voluntary feed intake, and feeding a high-energy dense diet (>14.5 MJ DE/kg) improved only some indicators of piglet vitality. As no other measures were affected, the study concluded that energy intake of hyper-prolific sows is used with greater efficiency for piglet growth when sows are fed a low- versus a high-energy density lactation diet (Rooney et al., 2020a).

The effect of supplementing sow diets with enzymes between day 109 of gestation and the following service was investigated as an alternative method to improve energy intake. Indeed, supplementation with a non-starch polysaccharide-hydrolysing enzyme increased energy intake during lactation for both gilts and sows. For gilts, the loss of body reserves (back-fat) at weaning was reduced (Walsh et al., 2012a), and in multiparous sows, the extra energy was reallocated to increasing litter weight gain, resulting in an increase in piglet weight at weaning (Cozannet et al., 2018).

Finally, one of the practical limitations to applying accurate nutritional recommendations for sows on commercial farms is that accurate sow weights are not always available. A simple equation using easily obtained morphometric measurements to estimate sow weight was developed; sow girth was the single most accurate estimator of body weight $\left(R^{2}=0.81\right)$, and, including back-fat thickness, parity number and day of gestation in the model improved the estimate further $\left(R^{2}=\right.$ 0.89; O'Connell et al., 2007).

\section{The newly weaned pig}

When planning routine management and nutrition programmes for weaned pigs, the influence of weaning age on post-weaning intake and growth is critical. A 1-kg increase in weaning weight results in a $1.7-\mathrm{kg}$ increase in weight at $28 \mathrm{~d}$ post weaning, and increasing weaning age by $1 \mathrm{~d}$ is associated with a 500-g increase in weight at that time (Lawlor et al., 2003a). In addition, each weekly increase in weaning age between 3 and 5 wk increased feed intake (week 3 to 4 : $13 \%$, week 4 to $5: 69 \%$ ) and ADG of pigs between weaning and $10 \mathrm{wk}$ of age (week 3 to $4: 11 \%$, week 4 to 5 : $67 \%$; Leliveld et al., 2013). Thus, Teagasc recommends that pigs are weaned at a minimum of $4 \mathrm{wk}$ of age. From this age, pigs can better digest and absorb dietary nutrients. Therefore, they have increased growth and less post-weaning diarrhoea, both of which are increasingly important in light of the impending ban on pharmacological levels of zinc oxide in post-weaning diets, which, to date, has been used as prophylaxis against post-weaning diarrhoea.

Pigs that are heavier at birth outperform their lighter littermates post weaning, and reach slaughter weight sooner (Lawlor et al., 2002a, 2005a). However, Teagasc studies found no clear relationship between increasing global nutrition of the sow (increased feed intake rather than an increase in specific nutrients) or energy supply at critical nutritional windows on piglet birth weight (Lawlor et al., 2007b; Markham et al., 2009; McNamara et al., 2011). Although weaning weight is increased by supplementing piglets with creep feed in the farrowing pen, this advantage can be lost by $14 \mathrm{~d}$ post weaning (Lawlor et al., 2002a), most likely dependent on the proportion of pigs within the post-weaning group that have consumed creep feed and so classified as "eaters". Thus, to minimise the weaning "growth lag", in late 2020 Teagasc commenced a 4-yr research programme aimed at increasing energy and nutrient intake, and stimulating earlier enzyme secretory capacity, in suckling piglets from large litters, by feeding liquid milk replacer and starter diets prior to weaning.

The post-weaning growth lag, normally experienced by pigs, is due not only to the change in feed consistency and reduced feed intake, but also to a limited digestive and absorptive capacity, resulting from insufficient production of gastric hydrochloric acid and pancreatic enzymes. Feeding organic acids or reducing the acid-binding capacity of post-weaning diets helped increase intake and growth with the benefit being greatest when diets contained low levels of milk products. These strategies are beneficial because they supplement the newly weaned pig's limited capacity to produce gastric 
hydrochloric acid (Lawlor et al., 2005a, 2005b, 2006). These strategies are now widely used in the commercial production of post-weaning pig diets, and the work is receiving renewed attention due to the previously mentioned changes to the regulations with regard to veterinary medicinal products.

\section{Ingredients and feed delivery}

Although post-weaning growth rate is increased by feeding high levels of milk powder in diets immediately after weaning, and time taken to reach slaughter weight is reduced, feeding excessive levels of these expensive diets post weaning was not cost-effective (Lawlor et al., 2002a, 2003b, 2005a). Thus, Teagasc recommend that a target of $2 \mathrm{~kg} / \mathrm{pig}$ of starter diet and $5 \mathrm{~kg} / \mathrm{pig}$ of link diet (a diet intermediate in composition between that of a starter and a weaner diet) should be fed post weaning. Alternatively, a starter diet should be fed for 7 $10 \mathrm{~d}$ post weaning followed by a link diet for another 12-14 d. Heat-treated (steam-flaked, micronised, expanded, extruded, etc.) cereals were also once common in post-weaning diets, but are expensive, and Teagasc research demonstrated that although starch was effectively gelatinised by the process, the heat processing did not significantly improve animal growth or FE (Lawlor et al., 2003a, 2003b). Therefore, it is no longer recommended to include heat-processed maize and wheat in post-weaning pig diets.

In the early 2000s, it was thought that liquid feeding could be a panacea for successful feeding of newly weaned pigs, so a series of trials in which pigs were liquid-fed (fresh, fermented and acidified) for $28 \mathrm{~d}$ post weaning were performed in Teagasc. Contrary to popular opinion at the time, the practice was found to be quite wasteful of feed depending on the design of the feeding trough; in one trial, liquid feeding actually caused a reduction in growth rate (Lawlor et al., 2002b). As a result, very few liquid feed systems for weaned pigs were installed on Irish pig units, resulting in savings related to FE through reduced feed waste.

\section{Growing pigs}

\section{Feed enzymes}

There is now a move towards the use of novel ingredients and co-products in the pig industry in order to reduce feed costs. Although pig diets are primarily composed of ingredients of vegetable origin, pigs lack the enzymes needed to break down fibre and therefore cannot efficiently digest fibrous ingredients. However, supplementing the diet with enzymes could potentially improve nutrient availability and FE.

Two meta-analyses of data from the literature confirmed that dietary supplementation of multi-enzyme complexes appears to be the most consistent strategy to improve FE in both weaner and finisher pigs (Torres-Pitarch et al., 2017, 2019). Results were most consistent when maize-based diets were supplemented with mannanase, barley-based diets with protease and when the diets were low in nutrient and energy density. Experimental work confirmed that supplementing carbohydrases and phytase as a multi-enzyme complex to low-nutrient-density diets returned the growth and FE of the pigs, as well as metacarpal and foot areal bone mineral density, to the levels reached by pigs fed diets meeting nutrient recommendations (Lawlor et al., 2019).

Nevertheless, the results from other Teagasc studies were less consistent. Growth and FE of grower-finisher pigs fed a wheat-dried distillers grain with solubles and rape seed meal-based diet did not improve when supplemented with an enzyme complex containing phytase, carbohydrases and protease (Torres-Pitarch et al., 2018). Supplementation of xylanase and beta-glucanase to liquid diets increased nutrient digestibility in two liquid-feeding studies but improved FE in only one (Torres-Pitarch et al., 2020a, 2020b). Interestingly, when FE was improved due to enzyme supplementation, bacterial taxa in the gastrointestinal tract (GIT) that were correlated with increased pig growth increased in abundance, whereas in the experiment where FE was not improved, they did not. This may help to explain the inconsistency often observed between enzyme supplementation studies.

\section{Liquid feeding - growing finishing pigs}

Computerised liquid-feeding systems reduce on-farm labour because they can mix feed ingredients and automatically deliver complete diets to troughs. These systems feed more than $70 \%$ of Irish pigs, and were often installed when significant volumes of liquid co-products (e.g. liquid whey and skim milk) were readily available in Ireland. However, these co-products are no longer easily and cheaply sourced, and the systems require a high degree of skill to operate optimally. Indeed, there is clear evidence of uncontrolled spontaneous fermentation of liquid feed leading to amino acid degradation and a reduction in energy, on Irish pig farms (O'Meara et al., 2021). O'Meara et al. (2020a) found that wet/dry feeding a pelleted diet was the optimum method (out of six options) of feeding grow-finisher pigs as it maximised carcass growth and optimised FE; liquid feeding also maximised growth rate, but resulted in poorer FE. The question then was how to improve FE when liquid feeding. O'Meara et al. (2020b) found that a water-to-feed ratio of less than 3.5:1 on a DM basis optimised $\mathrm{FE}$, and could be lowered to $2.4: 1$ to reduce the manure volume. Benzoic acid in liquid feed did not improve growth or FE (O'Meara et al., 2020c), but an acid blend containing formic acid (SALMO-NIL ${ }^{\circledR}$ Dry LC; Nutri-Ad International NV, Turnhout, Belgium) did. Controlled cereal or whole diet fermentation did not improve FE (O'Meara et al., 2020d). Work on optimising feeding management and hygiene routines with liquid-feeding systems is continuing with the objective of improving FE. 


\section{Phase feeding}

The nutrient requirements of pigs change from birth to slaughter. Adjusting the nutritional composition of diets to these requirements (phase feeding) is important to minimise costs and reduce environmental impact. Feeding programmes for growing finishing pigs should include at least two to three diets, with a progressive reduction in nutrients, mainly protein. However, many Irish farms work with only one diet from 30 $40 \mathrm{~kg}$ to slaughter (Teagasc eProfit Monitor, 2020), as they often only have one feeding line. However, moving to diets with lower protein levels, especially around $80 \mathrm{~kg}$ to slaughter, results in important financial savings and reduces $\mathrm{N}$ excretion significantly (Goodband et al., 2017). This will be more important in the coming years as DAFM target an average crude protein level in pig diets of $<16 \%$.

\section{Gut microbiome and feed efficiency}

The bacteria present in the GIT play a role in nutrient digestion and metabolism, as well as development and regulation of the host immune response. Teagasc studies were among the first to show that this gut microbiome is associated with FE in pigs (McCormack et al., 2017, 2019a). However, many FEassociated bacterial taxa are present at low relative abundance, and few consistent reliable FE-associated bacteria were identified across different rearing environments (McCormack et al., 2019a). Furthermore, faecal microbiota transplantation of inocula derived from highly feed efficient pigs, to pregnant sows, and/or their offspring, was not effective in improving FE or slaughter weight of their offspring (McCormack et al., 2018), even if offspring were supplemented with the prebiotic inulin at weaning (McCormack et al., 2019b). Nevertheless, the existence of a number of growth- and FE-associated bacterial taxa within the gut microbiome of pigs means that microbiota-targeted strategies offer real potential to improve productivity in pigs (Gardiner et al., 2020). However, it is likely that the most appropriate strategy for the future is to select for production traits based on core functionality of the microbiome and to modulate overall functionality of the microbiome, rather than focusing on individual taxa per se.

\section{Carcass lesions}

Meat inspection ( $\mathrm{MI})$ determines the health of animals both prior to death (ante-mortem) and after death (post-mortem) to ensure meat quality and safety. MI findings are currently underutilised (EFSA, 2011), and relaying this information back to pig farmers could contribute to reducing carcass losses and improving pig welfare on farm (Harley et al., 2012a). In Ireland, carcass condemnation is a major source of financial loss in the pig industry (Harley et al., 2014), with abscessation caused by tail biting being one of the main reasons (Harley et al., 2012b). Furthermore, given the scale of the problem of tail biting for pig welfare (Boyle et al., 2021a), tail injuries are likely one of the most important carcass lesions to be recorded at MI (Harley et al., 2012b).

Tail lesions (TL) are strongly associated with farm productivity parameters, and are less common on farms that avail of record keeping through the Teagasc advisory service (van Staaveren et al., 2017a). They are also associated with lung pathologies at slaughter (Boyle et al., 2021a); thus they appear to be negatively associated with better management in general (Teixeira et al., 2016; van Staaveren et al., 2016). Apart from severe TL in the finisher stage, carcass TL can also identify farms with problems with poor body condition in the first weaner stage, and bursitis in the second weaner stage (van Staaveren et al., 2017b), and TL acquired both early and late in the production cycle are visible on the carcass (Carroll et al., 2018). Indeed, TL are best detected after scalding and dehairing rather than at ante-mortem inspection (Carroll et al., 2015). As mixing, transport, slaughter and carcass processing do not disrupt the visibility or presence of TL on the carcass (van Staaveren et al., 2015), there is a strong case for including measures of the severity of carcass TL in the MI process.

However, consultations with stakeholders revealed a preference to focus on lesions related to health (such as lung lesions) in the MI process as a first priority (van Staaveren et al., 2019). Thus, a programme of research to validate lung pathologies at Ml against coughing on farm (Pessoa et al., 2020) and to standardise methods of scoring was undertaken. Stakeholders also expressed positive attitudes towards the use of MI data to inform pig health and welfare if both standardisation of recording and feedback were improved, and if the Ml system could provide real-time benchmarking possibilities (van Staaveren et al., 2019). In 2021, DAFM rolled out a computerised antemortem recording system in Irish meat-processing plants, with a post-mortem system to follow in 2022. This will greatly improve feedback of information to producers, and will facilitate improvements to husbandry practices which are associated with lesions detectable on the carcass.

\section{Salmonella}

Salmonella carriage in pigs is a significant food safety concern (EFSA, 2008). A number of Teagasc studies investigated the epidemiology of Salmonella on Irish pig farms. On high seroprevalence farms, second-stage weaners had the highest rate of Salmonella shedding, closely followed by finishers and gilts, with monophasic variants of Salmonella Typhimurium predominating (Burns, 2015). However, sows do not appear to pose a major risk in the maintenance and transmission of Salmonella to their progeny, but instead the contaminated pen environment is more significant in on-farm perpetuation 
(Lynch et al., 2018). Although feed was found to play a role in the transmission of Salmonella to pigs, Salmonella prevalence in pig feed and feed ingredients is low (Burns, 2015; Burns et al., 2015). Interestingly, surveillance data highlighted feed form, biosecurity and disease control as significant factors associated with Salmonella infection on farrow-to-finish pig farms (Arguello et al., 2018).

Much Teagasc research investigated low-cost practical solutions to control Salmonella in pig production. In finisher pigs, supplementation with fumaric acid or a seaweed extract reduced intestinal counts of bacterial species indicative of pathogens such as Salmonella (Campbell et al., 2006; Gardiner et al., 2008). Supplementation with coated sodium butyrate or a blend of formic and citric acids and essential oils was effective in reducing Salmonella shedding and seroprevalence, but only in the absence of secondary infections (Walia et al., 2016, 2017a). In grower pigs, supplementation with these latter products also reduced Salmonella shedding and improved ADG (Lynch et al., 2017a, 2017b). In weaned pigs, a novel combination of five probiotic strains selected for their anti-Salmonella activity (Gardiner et al., 2004; Walsh et al., 2008) reduced Salmonella shedding (Casey et al., 2007). In addition, Arguello et al. (2019) revealed that gut microbiota composition and maturation (transition from a suckling to a post-weaning microbiota) appear to influence resistance to Salmonella infection in weaned pigs; thus, gut microbiota manipulation has potential to protect against infection.

Finally, Salmonella control strategies can also be effective when applied at the abattoir. Drying of lairage pens after cleaning with detergent and a chlorocresol-based disinfectant was the most effective hygiene routine to eliminate Salmonella contamination (Walia et al., 2017b). Topical misting of pigs in the lairage with a peroxygen disinfectant was also beneficial as a Salmonella decontaminant prior to slaughter (Walia et al., 2017c). These strategies should be adopted by the processing sector in an effort to reduce carcass contamination with Salmonella at the abattoir. The sanitisation strategies also have relevance in guiding on-farm hygiene routines.

In 2021, Animal Health Ireland (AHI) and Teagasc carried out a case-control study in Irish farms to identify management practices associated with a Salmonella-free status, which could be effective in reducing prevalence nationally. The outcome of this work will help further to implement the national Salmonella control programme.

\section{Feed safety}

\section{Genetically modified (GM) feed}

The Irish feed industry is highly reliant on imported GM protein sources, particularly soya and maize co-products. Teagasc research showed that both short- or long-term feeding of GM
Bt-maize, which expresses the truncated Cry1 $\mathrm{Ab}$ toxin from Bacillus thuringiensis which confers resistance to certain insect pests of maize, to pigs is as safe as its conventional counterpart with respect to pig health and growth (Buzoianu et al., 2012a, 2012b, 2012c; Walsh et al., 2011, 2012b, 2012c). Neither was there any cause for concern regarding the safety of peas expressing $\alpha$-amylase inhibitor to provide protection against the pea weevil (Walsh et al., in press). This work offers assurance to regulators, farmers and consumers alike as to the safety of GM feed ingredients in pigs of different ages, even when fed for extended periods or transgenerationally (Buzoianu et al., 2012d, 2013a, 2013b; Walsh et al., 2013). Given that pigs are an excellent model for humans (Bergen, 2022), this work also provides reassurance to consumers as to the safety of directly consuming these GM ingredients.

\section{Mycotoxins}

Mycotoxins are secondary metabolites produced by fungi, mainly the moulds Aspergillus, Penicillium and Fusarium. They affect $\sim 25 \%$ of the world's food crops, causing significant economic losses, as well as being a health concern in humans. A review conducted by Teagasc advised that if mycotoxin contamination is identified, the contaminated grain should be disposed of or, if safe to do so, diluted with clean grain and fed, along with a binder, to the least susceptible species and type of animal (Lawlor \& Lynch, 2001a). Following removal of contaminated feed, the storage area should then be thoroughly cleaned and disinfected to prevent cross-contamination. A follow-on review highlighted that the clinical response in pigs to mycotoxins can vary; vomitoxin causes pigs to refuse feed, zearalenone affects the reproductive organs, ochratoxin causes kidney damage and aflatoxins increase susceptibility to disease through their action as immunosuppressants and can also cause haemorrhages and digestive disorders (Lawlor \& Lynch, 2001b).

\section{Pig production and the environment}

Although the overall density of pig production expressed as agricultural area used per sow in Ireland $(26 \mathrm{ha} / \mathrm{sow})$ is relatively low (e.g. Netherlands, $1.9 \mathrm{ha} / \mathrm{sow}$; Denmark, $2.0 \mathrm{ha} / \mathrm{sow}$ ), the pig industry generates large volumes of animal manure on a small area of land. This must be managed in order to comply with national and EU environmental legislation. Since September 1996, pig farms above a certain size were incorporated under the Environmental Protection Agency (EPA) Act (1992) as "intensive agriculture" and require an Industrial Emissions Licence. This licensing regime was introduced on a phased basis; currently, if a facility exceeds 750 sows and/or 2000 production pigs (pigs $>30 \mathrm{kgLW}$ ), they must have an Industrial Emissions Licence, and 118 licences have been issued to date. 


\section{Management of pig manure}

Over the past 15-20yr, provision of low protein diets and phytase enzyme has greatly reduced the levels of $\mathrm{N}$ and $\mathrm{P}$ excreted, respectively. This was driven by research work showing that performance on farms was not negatively impacted by these strategies (Campbell \& Bedford, 1992; Hayes et al., 2004; Humer et al., 2015). The issue of managing slurry to ensure minimal impact on water resources was managed by a code of practice until 2005/2006 when the EU Good Agricultural Practice for Protection of Waters Regulations (the "nitrates" regulations) came into force. This requires all pig farms to have capacity for a $26-w k$ slurry storage. The regulations also encouraged better farmyard management by minimising the volumes of soiled water generated on farms.

There are a number of available technologies for using and treating pig manure (reviewed by Dennehy et al., 2017a). Those investigated by Teagasc include anaerobic digestion (Xie et al., 2011a, 2011b, 2012a, 2012b, 2017), composting (Nolan et al., 2011; Troy et al., 2012, 2013b) and pyrolysis (Troy et al., 2013a, 2013b, 2014). Treatment of the liquid fraction of pig manure through integrated constructed wetlands (ICW; Harrington et al., 2012), woodchip biofilters (Carney et al., 2013, 2016) and intermittently aerated sequencing batch reactors (Zhang et al., 2011, 2012) was also assessed. However, none of these technologies are currently cost-effective in Ireland, other than in limited scenarios (e.g. anaerobic digestion on integrated pig units with >2000 sows; Nolan et al., 2012). Thus, land spreading remains the most cost-effective use for pig manure in Ireland.

Pathogen removal was also investigated to assess potential biosafety risks, as antibiotic-resistant Salmonella, for example, is common in pig manure (McCarthy et al., 2013). Manure separation generated a solid fraction with lower faecal indicator counts than the manure (McCarthy et al., 2013), and storage for 84-112 d reduced/eliminated Salmonella, including antibiotic-resistant strains, in manure and its solid and liquid fractions (McCarthy et al., 2015b). Composting manure solids also reduced faecal indicators so that the compost complied with animal by-products regulations (McCarthy et al., 2011a). Treatment of the liquid fraction of anaerobically digested (AD) pig manure in meso-scale (midway between bench and pilot-scale) ICWs reduced indicator bacteria (McCarthy et al., 2011b). Furthermore, in on-farm ICWs treating agricultural wastewater, including the liquid fraction of $A D$ pig manure, and woodchip biofilters treating the liquid fraction of manure, Salmonella, including antibiotic-resistant strains, was undetectable in the effluent (McCarthy et al., 2011b, 2015a). Thus, management strategies can be successful in reducing pathogens, including antibiotic-resistant strains, in pig manure and its separated solid and liquid fractions.

A large body of Teagasc research was also performed on co-digestion of pig manure and food waste (FW).
At batch-scale, co-digestion had synergistic effects on specific methane yields and digestion kinetics (Dennehy et al., 2016). However, varying the digester feedstock composition did not affect digestate biosafety or dewaterability (Dennehy et al., 2018). Decreasing hydraulic retention time (HRT) from 41 to $21 \mathrm{~d}$ did not increase the counts of pathogenic indicator microorganisms (Dennehy et al., 2018), but reducing HRT below $21 \mathrm{~d}$ had a negative effect on indicator reduction rates (Dennehy et al., 2017a). Dennehy et al. (2018) also concluded that hydrogenotrophic methanogenesis may be a key methanogenic pathway at low HRTs (Dennehy et al., 2018). Further research into dry co-digestion of pig manure and FW focused on methane production kinetics, inactivation of Salmonella and enteric indicator bacteria, system stability and the roles of, and interaction amongst, microbes (Jiang et al., 2018a, 2018b, 2018c, 2019). Together with a review of the literature (Jiang et al., 2020), the conclusion was that for successful anaerobic co-digestion of pig manure and bio waste, operating conditions need to be optimised in order to mutually benefit energy recovery, pathogen inactivation, economic feasibility and bio waste stabilisation.

The final part of this research involved development of an economic model to assess the financial viability of on-farm biogas plants in Ireland (Dennehy et al., 2017b). Despite lower operational and capital expenditure than co-digestion, mono-digestion of pig manure was not financially viable. In terms of co-digestion, Monte Carlo simulation revealed that net revenues from a small farm were least sensitive to any future changes in FW availability, gate fees (fees charged by the anaerobic digester operator for disposal of the FW), digestate disposal costs and renewable energy feed-in tariff. Due to its potential to treat greater amounts of FW than a small farm, whilst requiring a lower amount of $\mathrm{FW}$ to remain profitable relative to a large farm, medium-sized farms had the highest revenue-generating potential under optimal market conditions (Dennehy et al., 2017b).

\section{What does the future hold for the Irish pig sector?}

The European pig sector currently faces challenges that could have significant long-term implications for the industry. These include ASF, volatility of feed prices and EU regulations in the areas of health (e.g. Regulation [EU] 2019/6 on veterinary medicines), welfare (e.g. Council Directive 2008/120/EC on minimum standards for the protection of pigs) and the environment. The Irish pig sector has an added challenge with Brexit due to the UK, along with China, taking a significant proportion of Irish pork exports. To face these challenges, it is essential that the industry as a whole improve standards of production. This includes not only investigating the potential to produce value-added products, but also optimising efficiency 
and innovation to ensure maintenance of existing presence in the domestic, European and international markets.

\section{Market opportunities}

In the short term, Irish pig exports will face a significant challenge when the Chinese pig herd recovers from the impact of ASF. The increased volume of global pig meat production will likely exceed demand, resulting in downward pressure on pig meat prices and margins. In the medium term, economic and population growth in developing countries will be the main drivers of meat consumption globally, which may provide new markets for Irish pig meat. Nonetheless, producers and processors face continuous challenges when competing in the international marketplace, ranging from high feed and energy costs to market access disruption, supply surges, currency fluctuations, etc.

Ireland currently has only a very small number of pig producers producing low volumes of potentially high-value products such as outdoor pigs and organic product. The vast majority $(99 \%)$ of our pig meat output is not a high-margin product (Teagasc, 2019). One way that the Irish pig meat industry could differentiate itself on the international markets is to develop a "bespoke" high value-added pig meat product. To this end, Teagasc researchers recently commenced market research into consumer demand for high-welfare pork, which will include interviews with major buyers (e.g. supermarkets, etc.) and economic analysis to determine the return needed to remain profitable, upon conversion to a higher-welfare system.

\section{Health and welfare}

A significant challenge for the pig industry across the EU is the growing emphasis on enforcement of Council Directive 2008/120/EC, which mandates that pigs should not be routinely tail docked to prevent tail biting, and provided with environmental enrichment that satisfies their behavioural needs. Moreover, the outcome of the recent European Citizen's Initiative to "End the Cage Age" and the EU's Farm to Fork Strategy will both see the enactment of additional pig welfare legislation in the coming decade. In addition, all EU countries must implement the Regulation (EU) 2019/6 on Veterinary Medicinal Products in 2022, effectively banning the routine use of in-feed antibiotics and zinc oxide. Such legislation will require significant changes in the way pigs are housed and managed. However, the risk factors for tail biting and poor health (and thus the need to use antibiotics/zinc) are similar (Boyle et al., 2021b), and as such, efforts to comply with both sets of legislation will be complementary.

Another change to pig farming in Ireland is likely to be a shift towards increasing the time that the sow has freedom of movement. Several producers already manage free lactation systems, and Teagasc research demonstrated that pigs from these systems perform better than those from standard crates (Kinane et al., 2021). Thus, "free" systems are likely to grow in popularity, and there is potential for entirely free farrowing systems to be adopted; plans are in place for conversion of half of the farrowing rooms in the Moorepark research unit to free farrowing pens. Adoption of such systems could form part of a marketing plan to enhance the image of Irish pig production both at home and internationally.

Finally, in 2021 DAFM committed to fund the largest pig welfare project to date on the island of Ireland, drawing together a collaboration between Teagasc, University College Dublin, Queens University Belfast and the Agri-Food and Biosciences Institute in Northern Ireland. Apart from investigating commercially feasible alternatives to current systems (provision of outdoor access to growing pigs, and investigation of a range of alternative enrichment materials), the work will explore the feasibility of outdoor and agroforestry pig production. This will include a social, economic and environmental lifecycle assessment, as well as an analysis of the economy of changing land use to alternative systems of pig production.

\section{Optimising system efficiency}

The Irish pig sector has fewer but bigger farms than many other countries, the management of which could benefit from specialisation and the establishment of superstructures for coordination and decision-making. In the long term, this could involve a shift from individual farms, the current norm, to vertical integration at a range of levels. However, in the immediate term, and on the basis of a 2-yr recently completed pilot study, Teagasc are co-ordinating a new project to bring LEAN methodologies (management practices to improve efficiencies by eliminating waste) to pig farms. The first aspect of the project will involve two pilot farms which will have their management and health systems evaluated, with the aim of shifting towards ceasing docking of pigs' tails. Another project that is currently underway is a feasibility study investigating whether the Moorepark Pig Production Model (Calderón Díaz et al., 2019) could be commercialised as a spin-out company. The aim would be that the model could be used as a consultancy tool to assist producers in improving biological and financial efficiency.

\section{Increased collaboration across industry stakeholders}

During the past $4 \mathrm{yr}$, Teagasc, DAFM and AHI worked to establish schemes to collect data on different areas of pig production such as biosecurity, welfare, slaughterhouse findings, antimicrobial use and Salmonella status (AHI, 2021). The launch of the AHI Pig HealthCheck programme, and the hiring of a programme manager to co-ordinate activities in 2019, streamlined this process. Activities included upskilling private veterinary practitioners in the pig sector in how to audit farms with regard to biosecurity and animal welfare, establishment of a database for recording the output of such, and co-ordinating, running and management of both a pig 
technical working group and a pig industry implementation group. Both of these groups include stakeholders from across the industry. These activities will enable robust benchmarking of current standards and help to improve efficiency of production and the quality of the pork produced in Ireland.

\section{Conclusion}

The pig industry worldwide faces an enormous challenge in terms of meeting demands for protein from a growing world population, while simultaneously improving pig health and welfare, minimising damage to the environment and remaining economically sustainable. The Teagasc vision is to increase profitability in the pig sector by producing environmentally sustainable and welfare-friendly pig meat to the highest safety and quality standards. Teagasc has an integrated approach to pig production research, advisory and education supported by a vast network of international collaborators and close contact with all of the major industry stakeholders. This, and the legacy of its success in the past $60 \mathrm{yr}$, means that the Teagasc PDD is in a strong position to assist the Irish pig industry in adapting to become a more resilient and sustainable industry for the future.

\section{References}

AHI. 2021. https://animalhealthireland.ie/programmes/pig-healthcheck/ [Accessed 4 Jan 2022].

Amdi, C., Giblin, L., Hennessy, A.A., Ryan, T., Stanton, C., Stickland, N.C. and Lawlor, P.G. 2013. Feed allowance and maternal backfat levels during gestation influence maternal cortisol levels, milk fat composition and offspring growth. Journal of Nutritional Science 2: e1.

Amdi, C., Giblin, L., Ryan, T., Stickland, N.C. and Lawlor, P.G. 2014. Maternal backfat depth in gestating sows has a greater influence on offspring growth and carcass lean yield than maternal feed allocation during gestation. Animal 8: 236-244.

Arguello, H., Manzanilla, E.G., Lynch, H., Walia, K., Leonard, F.C., Egan, J., Duffy, G., Gardiner, G.E. and Lawlor, P.G. 2018. Surveillance data highlights feed form, biosecurity and disease control as significant factors associated with Salmonella infection on farrow-to-finish pig farms. Frontiers in Microbiology 9: 187.

Arguello, H., Estellé, J., Leonard, F.C., Crispie, F., Cotter, P.D., O' Suillivan, O., Lynch, H., Walia, K., Duffy, G., Lawlor, P.G. and Gardiner, G.E. 2019. Influence of the intestinal microbiota on colonisation resistance to Salmonella and the shedding pattern of naturally exposed pigs. mSystems 4: e00021-e00119.

Bergen, W.G. 2022. Pigs (Sus Scrofa) in Biomedical Research. Advances in Experimental Medicine and Biology 1354: 335-343.
Bord Bia. 2021. Export Performance and Prospects 2020-2021, Dublin: Bord Bia. Available online: https://www.bordbia.ie/globalassets/ bordbia2020/industry/insights/performance--prospects/bord-biaexport-performance--prospects-2020--2021-1.pdf [Accessed 15 April 2021].

Boyle, L.A., Conneely, M., Kennedy, E., O'Connell, N., O'Driscoll, K. and Earley, B. 2021a. Animal welfare research - progress to date and future prospects. Submitted to Irish Journal of Agriculture and Food Research, March 2021.

Boyle, L.A., Edwards, S.A., Bolhuis, L., Pol, F., Zupan, M., Schütze, S., Nordgreen, J., Bozakova, N., Sossidou, E. and Valros, A. 2021b. The evidence for a causal link between disease and damaging behaviour in pigs. Under Revision for Frontiers in Veterinary Science, in Press.

Burns, A.M. 2015. Assessing and managing the risk posed by Salmonella in pig feed. Thesis submitted for the Degree of Doctor of Philosophy, Waterford Institute of Technology.

Burns, A.M., Lawlor, P.G., Gardiner, G.E., McCabe, E.M., Walsh, D., Mohammed, M., Grant, J. and Duffy, G. 2015. Salmonella occurrence and Enterobacteriaceae counts in pig feed ingredients and compound feed from feed mills in Ireland. Preventative Veterinary Medicine 121: 231-239.

Buzoianu, S.G., Walsh, M.C., Rea, M.C., Cassidy, J.P., Ross, R.P., Gardiner, G.E. and Lawlor, P.G. 2012a. Effect of feeding genetically modified Bt MON810 maize to 40 -day-old pigs for 110 days on growth and health indicators. Animal 6: 1609-1619.

Buzoianu, S.G., Walsh, M.C., Rea, M.C., O'Sullivan, O., Crispie, F., Cotter, P.D., Ross, R.P., Gardiner, G.E. and Lawlor, P.G. 2012b. The effect of feeding Bt MON810 maize to pigs for 110 days on intestinal microbiota. PLOS ONE 7: e33668.

Buzoianu, S.G., Walsh, M.C., Rea, M.C., O'Sullivan, O., Cotter, P.D., Ross, R.P., Gardiner, G.E. and Lawlor, P.G. 2012c. Highthroughput sequence-based analysis of the intestinal microbiota of weanling pigs fed genetically modified MON810 maize expressing Bacillus thuringiensis Cry1 Ab (Bt maize) for 31 days. Applied and Environmental Microbiology 78: 4217-4224.

Buzoianu, S.G., Walsh, M.C., Rea, M.C., O’Donovan, O., Gelencsér, E., Ujhelyi, G., Szabó, E., Nagy, A., Ross, R.P., Gardiner, G.E. and Lawlor, P.G. 2012d. Effects of feeding Bt maize to sows during gestation and lactation on maternal and offspring immunity and fate of transgenic material. PLOS ONE 7: e47851.

Buzoianu, S.G., Walsh, M.C., Rea, M.C., Quigley, L., O’Sullivan, O., Cotter, P.D., Ross, R.P., Gardiner, G.E. and Lawlor, P.G. 2013a. Sequence-based analysis of the intestinal microbiota of sows and their offspring fed genetically modified maize expressing a truncated form of Bacillus thuringiensis Cry1 Ab protein (Bt maize). Applied and Environmental Microbiology 79: 7735-7744.

Buzoianu, S.G., Walsh, M.C., Rea, M.C., Cassidy, J.P., Ryan, T.P., Ross, R.P., Gardiner, G.E., and Lawlor, P.G. 2013b. Transgenerational effects of feeding genetically modified maize to nulliparous sows and offspring on offspring growth and health. Journal of Animal Science 91: 318-330. 
Calderón Díaz, J.A., Boyle, L.A., Diana, A., Leonard, F.C., Moriarty, J.P., McElroy, M.C., McGettrick, S., Kelliher, D. and García Manzanilla, E. 2017. Early life indicators predict mortality, illness, reduced welfare and carcass characteristics in finisher pigs. Preventative Veterinary Medicine 146: 94-102.

Calderón Díaz, J., Garcia Manzanilla, E., Diana, A. and Boyle, L. 2018. Cross-fostering implications for pig mortality, welfare and performance. Frontiers in Veterinary Science 5: 123.

Calderón Díaz, J.A., Shalloo, L., Niemi, J., Kyriazakis, I., McKeon, M., McCutcheon, G., Bohan, A. and Manzanilla, E.G. 2019. Description and validation of the Teagasc Pig Production Model. Journal of Animal Science 97: 2867-2885.

Campbell, G.L. and Bedford, M.R. 1992. Enzyme applications for monogastric feeds: a review. Canadian Journal of Animal Science 72: 449-466.

Campbell, A.J., Gardiner, G.E., Leonard, F.C., Lynch, P.B., Stanton, C., Ross, R.P. and Lawlor, P.G. 2006. Effect of dietary supplementation of finishing pigs with organic acids or mannanoligosaccharide on the coliform, Lactobacillus and Bifidobacterium flora of intestinal contents and faeces. The Pig Journal 57: 90-104.

Carney, K.N., Rodgers, M., Lawlor, P.G. and Zhan, X. 2013. Treatment of separated piggery anaerobic digestate liquid using woodchip biofilters. Environmental Technology 34: 663-670.

Carney, K., Nolan, T., Lawlor, P. and Zhan, X. 2016. Pilot field demonstration of woodchip biofilters in the treatment of separated pig manure digestate. Environmental Engineering and Management Journal 15: 2267-2272.

Carroll, G.A., Boyle, L.A., Teixeira, D.L., van Staaveren, N., Hanlon, A. and O'Connell, N.E. 2015. Effects of scalding and dehairing of pig carcasses at abattoirs on the visibility of welfare-related lesions. Animal 28: 1-8.

Carroll, G.A., Boyle, L.A., Hanlon, A., Collins, L., Griffin, K., Friel, M., Armstrong, D. and O'Connell, N.E. 2018. What can carcass-based assessments tell us about the lifetime welfare status of pigs? Livestock Science 214: 98-105.

Casey, P.G., Gardiner, G.E., Casey, G., Bradshaw, B., Lawlor, P.G., Lynch, P.B., Leonard, F.C., Stanton, C., Ross, R.P., Fitzgerald, G.F. and Hill, C. 2007. A five-strain probiotic combination reduces pathogen shedding and alleviates disease signs in pigs challenged with Salmonella enterica serovar Typhimurium. Applied and Environmental Microbiology 73: 1858-1863.

Cozannet, P., Lawlor, P.G., Leterme, P., Devillard, E., Geraert, P.A., Rouffineau, F. and Preynat, A. 2018. Reducing BW loss during lactation in sows: a meta-analysis on the use of a nonstarch polysaccharide-hydrolyzing enzyme supplement. Journal of Animal Science 96: 2777-2788.

Dennehy, C., Lawlor, P.G., Croize, T., Jiang, Y., Morrison, L., Gardiner, G.E. and Zhan, X. 2016. Synergism and effect of high initial volatile fatty acid concentrations during food waste and pig manure anaerobic co-digestion. Waste Management 56: 173-180.

Dennehy, C., Lawlor, P.G., Gardiner, G.E., Jiang, Y., Cormican, P., McCabe, M.S. and Zhan, X. 2017a. Process stability and microbial community composition in pig manure and food waste anaerobic co-digesters operated at low HRTs. Frontiers of Environmental Science and Engineering 11: 4.

Dennehy, C., Lawlor, P.G., Gardiner, G.E., Jiang, Y., Shalloo, L. and Zhan, X. 2017b. Stochastic modelling of the economic viability of on-farm co-digestion of pig manure and food waste in Ireland. Applied Energy 205: 1528-1537.

Dennehy, C., Lawlor, P.G., McCabe, M.S., Cormican, P., Sheahan, J., Jiang, Y., Zhan, X. and Gardiner, G.E. 2018. Anaerobic codigestion of pig manure and food waste; effects on digestate biosafety, dewaterability, and microbial community dynamics. Waste Management 71: 532-541.

Environmental Protection Agency Act. 1992. Available online: https:// www.irishstatutebook.ie/eli/1992/act/7/enacted/en/print.html [Accessed 26 October 2021].

European Food Safety Authority (EFSA). 2008. Report of the task force on zoonoses data collection on the analysis of the baseline survey on the prevalence of Salmonella in slaughter pigs, in the EU, 2006-2007, Part A. The European Food Safety Authority Journal 135: 1-111.

EFSA Panels on Biological Hazards (BIOHAZ), on Contaminants in the Food Chain (CONTAM), and on Animal Health and Welfare (AHAW). 2011. Scientific Opinion on the public health hazards to be covered by inspection of meat (swine). EFSA Journal 9: 2351. [198 pp]. . Available online: www.efsa.europa.eu/efsajournal.

Gardiner, G.E., Casey, P.G., Casey, G., Lawlor, P.G., Lynch, P.B., Fitzgerald, G.F., Hill, C., Stanton, C. and Ross, R.P. 2004. Relative ability of orally administered Lactobacillus murinus to predominate and persist in the porcine gastrointestinal tract. Applied and Environmental Microbiology 70: 1895-1906.

Gardiner, G.E., Campbell, A.J., O'Doherty, J.V., Pierce, E., Lynch, P.B., Leonard, F.C., Stanton, C., Ross, R.P. and Lawlor, P.G. 2008. Effect of Ascophyllum nodosum extract on growth performance, nutrient digestibility, carcass characteristics and selected intestinal microflora populations of grower-finisher pigs. Animal Feed Science and Technology 141: 259-273.

Gardiner, G.E., Metzler-Zebeli, B.U. and Lawlor, P.G. 2020. Impact of intestinal microbiota on growth and feed efficiency in pigs: a review. Microorganisms 8: 1886.

Goodband, B., Tokach, M., Woodworth, J., Dritz, S. and DeRouchey, J. 2017. Is phase feeding really worth the hassle? Teagasc Pig Farmers Conference P57-P64.

Harley, S., More, S., Boyle, L.A., O' Connell, N.E. and Hanlon, A. 2012a. Good animal welfare makes economic sense: potential of swine abattoir meat inspection as a welfare surveillance tool. Irish Veterinary Journal 65: 11.

Harley, S., More, S.J., O'Connell, N., Hanlon, A., Teixeira, D. and Boyle, L. 2012b. Evaluating the prevalence of tail biting and carcase condemnations in slaughter pigs in the republic and Northern Ireland, and the potential of abattoir meat inspection as a welfare surveillance tool. Veterinary Record 171: 621.

Harley, S., Boyle, L., O'Connell, N., More, S., Teixeira, D. and Hanlon, A. 2014. Docking the value of pigmeat? Prevalence and financial 
implications of welfare lesions in Irish slaughter pigs. Animal Welfare 23: 275-285.

Harrington, C., Scholz, M., Culleton, N. and Lawlor, P.G. 2012. The use of integrated constructed wetlands (ICW) for the treatment of separated swine wastewaters. Hydrobiologia 692: 111-119.

Hayes, E.T., Leek, A.B.G., Curran, T.P., Dodd, V.A., Carton, O.T., Beattie, V.E. and O'Doherty, J.V. 2004. The influence of diet crude protein level on odour and ammonia emissions from finishing pig houses. Bioresource Technology 91: 309-315.

Humer, E., Schwarz, C. and Schedle, K. 2015. Phytate in pig and poultry nutrition. Journal of Animal Physiology and Animal Nutrition 99: 605-625.

Jiang, Y., Dennehy, C., Lawlor, P.G., Hu, Z., McCabe, M., Cormican, P., Zhan, X. and Gardiner, G.E. 2018a. Inhibition of volatile fatty acids on methane production kinetics during dry co-digestion of food waste and pig manure. Waste Management 79: 302-311.

Jiang, Y., Dennehy, C., Lawlor, P.G., Hu, Z., Yang, Q., McCarthy, G., Tan, S.P., Zhan, X. and Gardiner, G.E. 2018b. Inactivation of Salmonella during dry co-digestion of food waste and pig manure. Waste Management 82: 231-240.

Jiang, Y., Dennehy, C., Lawlor, P.G., Hu, Z., Zhan, X. and Gardiner, G.E. 2018c. Inactivation of enteric indicator bacteria and system stability during dry co-digestion of food waste and pig manure. Science of the Total Environment 612: 293-302.

Jiang, Y., Dennehy, C., Lawlor, P.G., Hu, Z., McCabe, M., Cormican, P., Zhan, X. and Gardiner, G.E. 2019. Exploring the roles of and interactions among microbes in dry co-digestion of food waste and pig manure using high-throughput $16 \mathrm{~S}$ rRNA gene amplicon sequencing. Biotechnology for Biofuels 12: 5.

Jiang, Y., Xie, S.H., Dennehy, C., Lawlor, P.G., Hu, Z.H., Wu, G.X., Zhan, X.M. and Gardiner, G.E. 2020. Inactivation of pathogens in anaerobic digestion systems for converting biowastes to bioenergy: a review. Renewable and Sustainable Energy Reviews 120: 109654.

Kinane, O., Butler, F. and O'Driscoll, K. 2021. Freedom to grow: Improving sow welfare also benefits piglets. Animals 11: 1181.

Lawlor, P.G. and Lynch, P.B. 2001a. Mycotoxins in pig feeds. 1. Source of toxins; prevention and management of mycotoxicosis. Irish Veterinary Journal 54: 117-120.

Lawlor, P.G. and Lynch, P.B. 2001b. Mycotoxins in pig feeds. 2. Clinical aspects. Irish Veterinary Journal 54: 172-176.

Lawlor, P.G., Lynch, P.B., Caffrey, P.J. and O'Doherty, J.V. 2002a. Effect of pre- and post-weaning management on subsequent pig performance to slaughter and carcass quality. Animal Science 75: 245-256.

Lawlor, P.G., Lynch, P.B., Gardiner, G.E., Caffrey, P.J. and O'Doherty, J.V. 2002b. Effect of liquid feeding weaned pigs on growth performance to harvest. Journal of Animal Science 80: 1725-1735.

Lawlor, P.G., Lynch, P.B., Caffrey, P.J. and O'Doherty, J.V. 2003a. Effect of cooking wheat and maize on the performance of newly weaned pigs: 1. Age and weight at weaning. Animal Science 76: 251-261.
Lawlor, P.G., Lynch, P.B., Caffrey, P.J. and O'Doherty, J.V. 2003b. Effect of cooking wheat and maize on the performance of newly weaned pigs: 2. Level of dairy products and sequence of feeding. Animal Science 76: 263-271.

Lawlor, P.G., Lynch, P.B. and Caffrey, P.J. 2005a. Effect of creep feeding, dietary fumaric acid and level of dairy product in the diet on post-weaning pig performance. Irish Journal of Agricultural and Food Research 44: 45-55.

Lawlor, P.G., Lynch, P.B., Caffrey, P.J., O'Reilly, J.J. and O'Connell, M.K. 2005b. Measurements of the acid-binding capacity of ingredients used in pig diets. Irish Veterinary Journal 58: 447-452.

Lawlor, P.G., Lynch, P.B. and Caffrey, P.J. 2006. Effect of fumaric acid, calcium formate and mineral levels in diets on the intake and growth performance of newly weaned pigs. Irish Journal of Agricultural and Food Research 45: 61-71.

Lawlor, P.G., Lynch, P.B., O'Connell, M.K., Hiet, C. and Mattras, D. 2007a. Manipulation of liquid feed curves during lactation to increase sow feed intake and its impact on sow weight and backfat and piglet performance to weaning. In: 58th Annual Meeting of the European Association for Animal Production, pages 325.

Lawlor, P.G., Lynch, P.B., O'Connell, M.K., McNamara, L., Reid, P. and Stickland, N.C. 2007b. The influence of over feeding sows during gestation on reproductive performance and pig growth to slaughter. Archiv fur Tierzucht 50: 82-91.

Lawlor, P.G., Cozannet, P., Ryan, W.F. and Lynch, P.B. 2019. Effect of a combination phytase and carbohydrolase enzyme supplement on growth performance and bone mineralization of pigs from six weeks to slaughter at $105 \mathrm{~kg}$. Livestock Science 223: 144-150.

Leliveld, L.M.C., Riemensperger, A.V., Gardiner, G.E., O'Doherty, J.V., Lynch, P.B. and Lawlor, P.G. 2013. Effect of weaning age and postweaning feeding programme on the growth performance of pigs to 10 weeks of age. Livestock Science 157: 225-233.

Lynch, H., Leonard, F.C., Walia, K., Lawlor, P.G., Duffy, G., Fanning, S., Markey, B.K., Brady, C., Gardiner, G.E. and ArguelloRodriguez, H. 2017a. Investigation of in-feed organic acids as a low cost strategy to combat Salmonella in grower pigs. Preventive Veterinary Medicine 139: 50-57.

Lynch, H., Argüello, H., Walia, K., Lawlor, P.G., Duffy, G., Gardiner, G.E. and Leonard, F.C. 2017b. Evaluation of an alternative experimental infection method which closely mimics the natural route of transmission of monophasic Salmonella Typhimurium in pigs. Foodborne Pathogens and Disease 14: 23-28.

Lynch, H., Walia, K., Leonard, F.C., Lawlor, P.G., Manzanilla, E.G., Grant, J., Duffy, G., Gardiner, G.E., Cormican, M., King, J., Markey, B.K., Fanning, S. and Argüello, H. 2018. Salmonella in breeding pigs: shedding pattern, transmission of infection and the role of environmental contamination in Irish commercial farrow-to-finish herds. Zoonoses and Public Health 65: e196-e206.

Markham, T.C.W., Latorre, R.M., Lawlor, P.G., Ashton, C.J., McNamara, L.B., Natter, R., Rowlerson, A. and Stickland, N.C 2009. Developmental programming of skeletal muscle phenotype/ metabolism. Animal 3: 1001-1012. 
McCarthy, G., Lawlor, P.G., Coffey, L., Nolan, T., Gutierrez, M. and Gardiner, G.E. 2011a. An assessment of pathogen removal during composting of the separated solid fraction of pig manure. Bioresource Technology 102: 9059-9067.

McCarthy, G., Lawlor, P.G., Harrington, C. and Gardiner, G.E. 2011b. Microbial removal from the separated liquid fraction of anaerobically digested pig manure in meso-scale integrated constructed wetlands. Bioresource Technology 102: 9425-9431.

McCarthy, G., Lawlor, P.G., Gutierrez, M. and Gardiner, G.E. 2013. Assessing the biosafety risks of pig manure for use as a feedstock for composting. Science of the Total Environment 463-464: 712-719.

McCarthy, G., Lawlor, P.G., Carney, K.N., Zhan, X., Gutierrez, M. and Gardiner, G.E. 2015a. An investigation into the removal of salmonella and enteric indicator bacteria from the separated liquid fraction of raw or anaerobically digested pig manure using novel on-farm woodchip biofilters. Science of the Total Environment 514: 140-146.

McCarthy, G., Lawlor, P.G., Gutierrez, M., O'Sullivan, L., Murphy, A., Zhan, X. and Gardiner, G.E. 2015b. An assessment of salmonella survival in pig manure and its separated solid and liquid fractions during storage. Journal of Environmental Science and Health Part B Pesticides, Food Contaminants, and Agricultural Wastes 50: 135-145.

McCormack, U.M., Curião, T, Buzoianu, S.G., Prieto, M.L., Ryan, T., Varley, P., Crispie, F., Magowan, E., Metzler-Zebeli, B.U., Berry, D., O'Sullivan, O., Cotter, P.D., Gardiner, G.E. and Lawlor, P.G. 2017. Exploring a possible link between the intestinal microbiota and feed efficiency in pigs. Applied and Environmental Microbiology 83: e00380-e00417.

McCormack, U.M., Curião, T., Wilkinson, T., Metzler-Zebeli, B.U., Reyer, H., Calderon-Diaz, J.A., Ryan, T., Crispie, F., Cotter, P.D., Creevey, C.J., Gardiner, G.E. and Lawlor, P.G. 2018. Faecal microbiota transplantation in gestating sows and/or neonatal offspring alters lifetime intestinal microbiota and growth in offspring. mSystems 3: e00134-e00217.

McCormack, U.M., Curião, T., Metzler-Zebeli, B.U., Wilkinson, T., Magowan, E., Berry, D.P., Reyer, H., Prieto, M.L., Buzoianu, S.G., Harrison, M., Rebeiz, N., Crispie, F., Cotter, P.D., O'Sullivan, O., Gardiner, G.E. and Lawlor, P.G. 2019a. Porcine feed efficiencyassociated intestinal microbiota and physiological traits: finding consistent cross-locational biomarkers for residual feed intake. mSystems 4: e00324-e00418.

McCormack, U.M., Curião, T., Metzler-Zebeli, B.U., Wilkinson, T., Reyer, H., Crispie, F., Cotter, P.D., Creevey, C.J., Gardiner, G.E. and Lawlor, P.G. 2019b. Seeking to improve feed efficiency in pigs through microbial modulation via faecal microbiota transplantation in sows and dietary supplementation of offspring with inulin. Applied and Environmental Microbiology 85: e01255e01319.

McNamara, L.B., Giblin, L., Markham, T., Stickland, N.C., Berry, D.P., O'Reilly, J.J., Lynch, P.B., Kerry, J.P. and Lawlor, P.G. 2011.
Nutritional intervention during gestation alters growth, body composition and gene expression patterns in skeletal muscle of pig offspring. Animal 5: 1195-1206.

Nolan, T., Troy, S.M., Healy, M.G., Kwapinski, W., Leahy, J.J. and Lawlor, P.G. 2011. Characterization of compost produced from separated pig manure and a variety of bulking agents at low initial $\mathrm{C} / \mathrm{N}$ ratios. Bioresource Technology 102: 7131-7138.

Nolan, T., Troy, S.M., Gilkinson, S., Frost, P., Xie, S., Zhan, X., Harrington, C., Healy, M.G. and Lawlor, P.G. 2012. Economic analyses of pig manure treatment options in Ireland. Bioresource Technology 105: 15-23.

O'Connell, M.K., Lynch, P.B., Bertholot, S., Verlait, F. and Lawlor, P.G. 2007. Measuring changes in physical size and predicting weight of sows during gestation. Animal 1: 1335-1343.

O'Driscoll, K. and Schmitt, O. 2016. "Giving piglets the best start in life”. Teagasc Pig Newsletter October 2016.

O'Meara, F.M., Gardiner, G.E., O'Doherty, J.V. and Lawlor, P.G. 2020a. The effect of feed form and delivery method on feed microbiology and growth performance in grow-finisher pigs. Journal of Animal Science 98: skaa021. Available online: https://doi.org/10.1093/jas/ skaa021.

O'Meara, F.M., Gardiner, G.E., O'Doherty, J.V. and Lawlor, P.G. 2020 b. Effect of water-to-feed ratio on feed disappearance, growth rate, feed efficiency, and carcass traits in growing-finishing pigs. Translational Animal Science 4: 630-640.

O'Meara, F.M., Gardiner, G.E., O'Doherty, J.V. and Lawlor, P.G. 2020c. Effect of dietary inclusion of benzoic acid (VevoVitall $®$ ) on the microbial quality of liquid feed and the growth and carcass quality of grow-finisher pigs. Livestock Science 237: 104043.

O'Meara, F.M., Gardiner, G.E., O'Doherty, J.V., Clarke, D., Cummins, W. and Lawlor, P.G. 2020d. Effect of wet/dry, fresh liquid, fermented whole diet liquid, and fermented cereal liquid feeding on feed microbial quality and growth in grow-finisher pigs. Journal of Animal Science 98: skaa166. Available online: https://doi. org/10.1093/jas/skaa166.

O’Meara, F.M., Gardiner, G.E., Clarke, D., Cummins, W., O’Doherty, J.V. and Lawlor, P.G. 2021. Microbiological assessment of liquid feed for finisher pigs on commercial pig units. Journal of Applied Microbiology 130: 356-369.

Pessoa, J., da Costa, M.R., Manzanilla, E.G., Norton, T., McAloon, C. and Boyle, L.A. 2020. Managing respiratory disease in finisher pigs: combining quantitative assessments of clinical signs and the prevalence of lung lesions at slaughter. Preventative Veterinary Medicine 186: 105208.

Reid, K., O'Driscoll, K., Magowan, E., O'Doherty, J. and Lawlor, P. 2016. I-arginine and I-carnitine in gestating sow diets to optimise output and piglet growth. Proceedings of the 67th Annual Meeting of the European Federation of Animal Science, Belfast, NI.

Rooney, H.B., O'Driscoll, K., O'Doherty, J.V. and Lawlor, P.G. 2019. Effect of I-carnitine supplementation and sugar beet pulp inclusion in gilt gestation diets on gilt live weight, lactation feed intake, and 
offspring growth from birth to slaughter. Journal of Animal Science 97: 4208-4218.

Rooney, H.B., O'Driscoll, K., O'Doherty, J.V. and Lawlor, P.G. 2020a. Effect of increasing dietary energy density during late gestation and lactation on sow performance, piglet vitality, and lifetime growth of offspring. Journal of Animal Science 98: skz379. Available online: https://doi.org/10.1093/jas/skz379.

Rooney, H.B., O'Driscoll, K., Silacci, P., Bee, G., O'Doherty, J.V. and Lawlor, P.G. 2020b. Effect of dietary L-carnitine supplementation to sows during gestation and/or lactation on sow productivity, muscle maturation and lifetime growth in progeny from large litters. British Journal of Nutrition 124: 43-56.

Ryan, T., Lynch, P.B. and Lawlor, P.G. 2009. Comparison between computerised liquid feeding and ad libitum dry feeding for sows during lactation. In: "60th Annual Meeting of the European Association for Animal Production", Barcelona, Spain.

Schmitt, O., Baxter, E., Boyle, L. and O'Driscoll, K. 2019a. Nurse sow strategies in the domestic pig (Sus Scrofa): I. Consequences for the selected measures of sow welfare. Animal 13: 580-589.

Schmitt, O., Baxter, E., Boyle, L. and O'Driscoll, K. 2019b. Nurse sow strategies in the domestic pig (Sus Scrofa): II. Consequences piglet growth, suckling behaviour, and sow nursing behaviour. Animal 13: 590-599.

Schmitt, O., O'Driscoll, K., Boyle, L. and Baxter, E. 2019c. Artificial rearing affects piglets pre-weaning behaviour, welfare and growth performance. Applied Animal Behaviour Science 210: 16-25.

Teagasc. 2019. "Teagasc Pig Farmers' Conference, Fermoy": Teagasc. Available online: https://www.teagasc.ie/media/website/ publications/2019/Teagasc-Pig-Farmers-Conference-2019.pdf [Accessed 15 April 2021].

Teagasc eProfit Monitor. 2020. Personal communication with Ger McCutcheon, pig eProfitMonitor manager: https://www.teagasc. ie/animals/pigs/advice/herd-performance-monitoring/ [Accessed 4 Jan 2022].

Teagasc. 2021. Personal communication with Ciaran Carroll, head of Knowledge Transfer in the Teagasc Pig Development Department.

Teixeira, D.L., Harley, S., Hanlon, A., O'Connell, N.E., More, S., Manzanilla, E.G. and Boyle, L.A. 2016. Study on the association between tail lesion score, cold carcass weight and viscera condemnations in slaughter pigs. Frontiers in Veterinary Science 3: 24.

Torres-Pitarch, A., Hermans, D., Manzanilla, E.G., Bindelle, J., Everaert, N., Beckers, Y., Torrallardona, D., Bruggeman, G., Gardiner, G.E. and Lawlor, P.G. 2017. Effect of feed enzymes on digestibility and growth in weaned pigs: a systematic review and meta-analysis. Animal Feed Science and Technology 233: 145-159.

Torres-Pitarch, A., McCormack, U.M., Beattie, V.E., Magowan, E., Gardiner, G.E., Pérez-Vendrell, A.M., Torrallardona, D., O’Doherty, J.V. and Lawlor, P.G. 2018. Effect of phytase, carbohydrase, and protease addition to a wheat DDGS and rapeseed-based diet on in-vitro ileal digestibility, growth and bone mineral density of growing-finishing pigs. Livestock Science 216: 94-99.
Torres-Pitarch, A., Manzanilla, E.G., Gardiner, G.E., O'Doherty, J.V. and Lawlor, P.G. 2019. Systematic review and meta-analysis of the effect of feed enzymes on growth and nutrient digestibility in grow-finisher pigs: effect of enzyme type and cereal source. Animal Feed Science and Technology 251: 153-165.

Torres-Pitarch, A., Gardiner, G.E., Cormican, P., Rea, M., Crispie, F., O'Doherty, J.V., Cozannet, P., Ryan, T., Cullen, J. and Lawlor, P.G. 2020a. Effect of cereal fermentation and carbohydrase supplementation on growth, nutrient digestibility and intestinal microbiota in liquid-fed grow-finishing pigs. Scientific Reports 10: 13716.

Torres-Pitarch, A., Gardiner, G.E., Cormican, P., Rea, M., Crispie, F., O'Doherty, J.V., Cozannet, P., Ryan, T. and Lawlor, P.G. 2020b. Effect of cereal soaking and carbohydrase supplementation on growth, nutrient digestibility and intestinal microbiota in liquid-fed grow-finishing pigs. Scientific Reports 10: 1023.

Troy, S.M., Nolan, T., Kwapinski, W., Leahy, J.J., Healy, M.G. and Lawlor, P.G. 2012. Effect of sawdust addition on composting of separated raw and anaerobically digested pig manure. Journal of Environmental Management 111: 70-77.

Troy, S.M., Lawlor, P.G., O'Flynn, C.J. and Healy, M.G. 2013a. Impact of biochar addition to soil on greenhouse gas emissions following pig manure application. Soil Biology and Biochemistry 60: 173-181.

Troy, S.M., Nolan, T., Leahy, J.J., Lawlor, P.G., Healy, M.G. and Kwapinski, W. 2013b. Effect of sawdust addition and composting of feedstock on renewable energy and biochar production from pyrolysis of anaerobically digested pig manure. Biomass and Bioenergy 49: 1-9.

Troy, S.M., Lawlor, P.G., O'Flynn, C.J. and Healy, M.G. 2014. The impact of biochar addition on nutrient leaching and soil properties from tillage soil amended with pig manure. Water, Air, and Soil Pollution 225.

van Staaveren, N., Teixeira, D.L., Hanlon, A. and Boyle, L.A. 2015. The effect of mixing entire male pigs prior to transport to slaughter on behaviour, welfare and carcass lesions. PLoS One 10: 1-15.

van Staaveren, N., Vale, A.P., Manzanilla, E.G., Teixeira, D.L., Leonard, F.C., Hanlon, A. and Boyle, L.A. 2016. Relationship between tail lesions and lung health in Irish slaughter pigs. Preventative Veterinary Medicine 127: 21-26.

van Staaveren, N., Teixeira, D.L., Hanlon, A. and Boyle, L.A. 2017a. Pig carcass tail lesions: the influence of record keeping through an advisory service and farm performance parameters. Animal 11: 140-146.

van Staaveren, N., Doyle, B., Manzanilla, E.G., Calderón Díaz, J.A., Hanlon, A. and Boyle, L.A. 2017b. Validation of tail lesions measured on the carcass as indicators for on-farm health and welfare. Journal of Animal Science. 95: 1528-1536.

van Staaveren, N., Doyle, B., Hanlon, A. and Boyle, L.A. 2019. Multistakeholder focus groups on potential for meat inspection data to inform management of pig health and welfare on farm. Agriculture 9: 40. 
Walia, K., Argüello, H., Lynch, H., Leonard, F.C., Grant, J., Yearsley, D., Kelly, S., Duffy, G., Gardiner, G.E. and Lawlor, P.G. 2016. Effect of feeding sodium butyrate in the late finishing period on salmonella carriage, seroprevalence, and growth of finishing pigs. Preventative Veterinary Medicine 131: 79-86.

Walia, K., Argüello, H., Lynch, H., Leonard, F.C., Grant, J., Yearsley, D., Kelly, S., Duffy, G., Gardiner, G.E. and Lawlor, P.G. 2017 a. Effect of strategic administration of an encapsulated blend of formic acid, citric acid, and essential oils on salmonella carriage, seroprevalence, and growth of finishing pigs. Preventative Veterinary Medicine 137: 28-35.

Walia, K., Argüello, H., Lynch, H., Grant, J., Leonard, F.C., Lawlor, P.G., Gardiner, G.E. and Duffy, G. 2017b. The efficacy of different cleaning and disinfection procedures to reduce salmonella and enterobacteriaceae in the lairage environment of a pig abattoir. International Journal of Food Microbiology 246: 64-71.

Walia, K., Lynch, H., Grant, J., Duffy, G., Leonard, F.C., Lawlor, P.G. and Gardiner, G.E. 2017c. The efficacy of disinfectant misting in the lairage of a pig abattoir to reduce Salmonella and Enterobacteriaceae on pigs prior to slaughter. Food Control 75: 55-61.

Walsh, M.C., Gardiner, G.E., Hart, O.M., Daly, M., Lynch, P.B., Lawlor, P.G., Richert, B.T., Radcliffe, J.S., Giblin, L., Hill, C., Fitzgerald, G.F., Stanton, C. and Ross, R.P. 2008. Predominance of a bacteriocin-producing lactobacillus salivarius component of a fivestrain probiotic in the porcine ileum and effects on host immune phenotype. FEMS Microbiology Ecology 64: 317-327.

Walsh, M.C., Buzoianu, S.G., Gardiner, G.E., Rea, M.C., Gelencsér, E., Jánosi, A., Epstein, M.M., Ross, R.P. and Lawlor, P.G. 2011. Fate of transgenic DNA from orally administered Bt MON810 maize and effects on immune response and growth in pigs. PLOS One 6: e27177.

Walsh, M.C., Geraert, P.A., Maillard, R., Kluess, J. and Lawlor, P.G. 2012a. The effect of a non-starch polysaccharide-hydrolysing enzyme (Rovabio ${ }^{\circledR}$ Excel) on feed intake and body condition of sows during lactation and on progeny growth performance. Animal 6: 1627-1633.

Walsh, M.C., Buzoianu, S.G., Rea, M.C., O'Donovan, O., Gelencser, E., Ujhelyi, G., Ross, R.P., Gardiner, G.E. and Lawlor, P.G. 2012b. Effects of feeding Bt MON810 maize to pigs for 110 days on peripheral immune response and digestive fate of the cry1 Ab gene and truncated Bt toxin. PLoS One 7: e36141.
Walsh, M., Buzoianu, S.G., Gardiner, G.E., Rea, M., Ross, R.P., Cassidy, J.P. and Lawlor, P.G. 2012c. Effects of short-term feeding of Bt MON810 maize on growth performance, organ morphology and function in pigs. British Journal of Nutrition 107: 364-371.

Walsh, M.C., Buzoianu, S.G., Gardiner, G.E., Rea, M.C., O'Donovan, O., Ross, R.P. and Lawlor, P.G. 2013. Effects of feeding Bt MON810 maize to sows during first gestation and lactation on maternal and offspring health indicators. British Journal of Nutrition 109: 873-881.

Wientjes, J.G.M., Soede, N.M., Peet-Schwering, C.M.C., van den Brand, H., and Kemp, B. 2012. Piglet uniformity and mortality in large organic litters: effects of parity and pre-mating diet composition. Livestock Science 144: 218229.

Xie, S., Frost, J.P., Lawlor, P.G., Wu, G. and Zhan, X. 2011a. Effects of thermo-chemical pre-treatment of grass silage on methane production by anaerobic digestion. Bioresource Technology 102: 8748-8755.

Xie, S., Lawlor, P.G., Frost, J.P., Hu, Z. and Zhan, X. 2011b. Effect of pig manure to grass silage ratio on methane production in batch anaerobic co-digestion of concentrated pig manure and grass silage. Bioresource Technology 102: 5728-5733.

Xie, S., Lawlor, P.G., Frost, J.P., Wu, G. and Zhan, X. 2012a. Hydrolysis and acidification of grass silage in leaching bed reactors. Bioresource Technology 114: 406-413.

Xie, S., Wu, G., Lawlor, P.G., Frost, J.P. and Zhan, X. 2012b. Methane production from anaerobic co-digestion of the separated solid fraction of pig manure with dried grass silage. Bioresource Technology 104: 289-297.

Xie, S., Lawlor, P.G., Frost, P., Dennehy, C.D., Hu, Z. and Zhan, X. 2017. A pilot scale study on synergistic effects of co-digestion of pig manure and grass silage. International Biodeterioration and Biodegradation 123: 244-250.

Zhang, M., Lawlor, P.G., Wu, G., Lynch, B. and Zhan, X. 2011. Partial nitrification and nutrient removal in intermittently aerated sequencing batch reactors treating separated digestate liquid after anaerobic digestion of pig manure. Bioprocess and Biosystems Engineering 34: 1049-1056.

Zhang, M., Lawlor, P.G., Li, J. and Zhan, X. 2012. Characteristics of nitrous oxide $\left(\mathrm{N}_{2} \mathrm{O}\right)$ emissions from intermittently-aerated sequencing batch reactors treating the separated liquid fraction of anaerobically digested pig manure. Water, Air, and Soil Pollution 223: 1973-1981. 